\title{
UNCLAIMED BANKRUPTCY DIVIDENDS AND AMENDED 66: FEDERAL CONFISCATION OF STATE ESCHEAT
}

Disposition of unclaimed bankruptcy dividends brings federal regulation into collision with state escheat powers. ${ }^{1}$ Not expressly granted to the federal government or denied to the states, and concomitant to control over the devolution of property, ${ }^{2}$ the power to escheat has universally been considered with-

1. These unclaimed funds usually stem from the return or nonnegotiation of dividend checks mailed by the trustee in bankruptcy. See In re Gubelman, 79 F.2d 976 (2d Cir. 1935); In re MacMasters, 60 F. Supp. 733 (S.D.N.Y. 1945). Generally, no claim is asserted because of the original creditor's death, dissolution or neglect. See Application of the People of New York, 138 F. Supp. 661, 666 n.3 (S.D.N.Y. 1956).

2. The power to escheat is an incident of the state's general authority over the devolution and disposition of property within its jurisdiction and is properly exercisable by virtue of sovereignty over the property owner or the situs of the property. See Connecticut Mut. Life Ins. Co. v. Moore, 333 U.S. 541, $560-62$ (1948); Standard Oil Co. v. New Jersey, 341 U.S. 428 (1951); of. Christianson v. King County, 239 U.S. 356 (1915), 29 HARv. L. REv. 455 (1916). Thus, a state, as part of a general scheme of succession, may provide for escheat of property belonging to its citizens upon their death intestate without heirs; and it may legislate for the escheat of dormant property found within its borders, irrespective of the citizenship of the original owner. Compare Mass. Ann. Laws c. 190, § 3(7) (Supp. 1956), with id. c. 168, \$31; PA. Stat. Ann. tit. 20, § 1.3(6) (Supp. 1956), with id. tit. 27, $\S 1,41$.

Where, as may be true of unclaimed bankruptcy dividends or court funds generally. the actual fund is in the Federal Treasury with disbursement controlled by a federal court, see note 9 infra, situs has been held to be within the state in which the federal court is situated. That state accordingly has jurisdiction to declare the fund escheated. Application of the People of New York, supra note 1. See also United States v. Klein, 106 F.2d 213 (3d Cir.), cert. denied, 308 U.S. 618 (1939); Shestack, Disposition of Unclaimed Property-A Proposed Model Act, 46 ILL. L. REv. 48, 68-70 (1951) ; Note, 46 YALE L.J. 878 (1937). Though no case has yet arisen, the intangible nature of an abandoned claim to court funds presents the possibility that the state of the missing claimant's last-known address would seek to adjudicate the ownership of a bankruptcy dividend due him. Such a proceeding might be honored by the federal courts. See Standard Oil Co. v. New Jersey, supra at 437-41 (situs of an intangible for escheat purposes within any state having power over the parties whose rights in the res are to be adjudicated) ; Connecticut Mut. Life Ins. Co. v. Moore, stpra at 548-49 (state jurisdiction dependent upon "contact" with transaction giving rise to abandoned claim); id. at 560-62 (dissenting opinion accepting proposition that state's sovereignty over its citizens justifies escheat of intangibles).

The possibility of conflicting escheat claims, exaggerated when a state seeks insurance funds and unclaimed corporate dividends, has brought forth a comparative deluge of commentary in an otherwise bare field. See, generally, Shestack, supra at 61-63 (insurance funds); Note, 58 Y ALE L.J. 628 (1949) (same); Note, 43 Ill. L. Rev. 709 (1948) (same); Note, 65 HARv. L. Rev. 1408 (1952) (corporate dividends) ; 56 CoLuMr. L. REv. S05 (1956) (same). Recent cases would adjust conflicting escheat claims against the state of lastknown address. See State v. American Sugar Refining Co., 20 N.J. 286, 119 A.2d 767 (1956) (state of incorporation's claim better than that of state of shareholder's last-known address) ; Matter of Menschefrend, 283 App. Div. 463, 128 N.Y.S.2d 738 (1st Dep't 1954) (state of owner's domicile has inferior claim); In re Rapoport's Estate, 317 Mich. 291, 26 
in the residual powers of the states. ${ }^{3}$ Nevertheless, when applied to funds over which the national government has a regulatory interest, state abandoned property laws may not infringe upon the requirements of federal policy. ${ }^{4}$ The courts have generally avoided subordinating state escheat claims by finding no real conflict with the federal legislation involved. ${ }^{5}$ Thus, specific federal legislation and the nature of the underlying power were both held not to require congressional control over the disposition of dormant federal bank

N.W.2d 777, cert. denied, 332 U.S. 764 (1947) (same); cf. UnIFoRM Disposition of UnCLaIMed Property ACT $\S 10$.

3. Historically, escheat was an incident of feudal tenure. The term applied to the reversion of realty to mesne lords, or to the crown in their absence, where the tenant died without heirs or had been attained for some crime. 1 Pollock \& Mattland, Tre History of English Law 351-52 (2d ed. 1899); Garrison, Escheats, Abandoned Property Acts, and Their Revenue Aspects, 35 Kx. L.J. $302-03$ (1947) ; Note, 46 Yale L.J. 878,879 (1937). Personalty passed to the crown as bona vacantia on the theory that the sovereign's right, absent an ascertainable owner, was superior to that of a stranger. Garrison, supra at 303 ; see ENEver, Bona VaCANTIA UNDER the LAW of ENGLAND 13-18 (1927). Later, when escheat was abolished in England, the sovereign also took title to land as bona vacantia. Garrison, supra at 303 . See also Williams, The Abolition of Eschcat, 69 L.J. 369, 370 (1930).

In the United States, the power to escheat is considered an incident of sovereignty, exercisable by the states over personalty and realty much in the fashion of the English sovereign's prerogative over bona vacantia. Standard Oil Co. v. New Jersey, supra note 2, at 435-36; Connecticut Mut. Life Ins. Co. v. Moore, supra note 2, at 560; Hamilton v. Brown, 161 U.S. 256, 263 (1896); Garrison, supra at 304; see Anderson Nat'1 Bank v. Luckett, 321 U.S. 233, 240 (1944); In re Melrose Ave., 234 N.Y. 48, 136 N.E. 235 (1922). And while, under feudal law, escheat was dependent upon actual failure of heirs, escheat in this country may be grounded upon a rebuttable presumption of death without heirs or of abandonment when property has remained unclaimed for certain periods. See N.Y. ABANd. Pkop. LAW $\$ \S 1200-01$; Garrison, supra at 304-05. The federal government is generally held not to have the power to escheat property within the jurisdiction of a state. American Loan \& Trust Co. v. Grand Rivers Co., 159 Fed. 775 (C.C.W.D. Ky. 1908) ; 67 CENT. L.J. 429 (1908); see Matter of Moneys Deposited in United States Dist. Court, 243 F.2d 443, 445, 447-48 (3d Cir. 1957) ; Application of the People of New York, 138 F. Supp. 661, 666-67 (S.D.N.Y. 1956) ; United States v. Klein, 303 U.S. 276, 279-82 (1938) ; Comment, 19 N.C.L. Rev. 372, 373 (1941). Cf. Mormon Church v. United States, 136 U.S. 1, 46-47 (1890) (federal government parens patriae for purpose of escheat and forfeiture of property in territories not granted statehood). See also Alaska v. First Nat'1 Bank, 41 F.2d 186 (9th Cir. 1930) (Alaska entitled through federal grant to escheat bonds in national bank within territory); Estate of Lindquist, 25 Cal. 2d 697, 154 P.2d 879 (1944) (pension fund conditionally granted by federal government returnable to federal government on grantee's death without heirs); Coakley v. Attorney Gen., 318 Mass. 508, 62 N.E.2d 659 (1945) (same).

4. First Nat'1 Bank v. California, 262 U.S. 366 (1923); Starr v. O'Connor, 118 F.2d 548 (6th Cir. 1941).

5. See United States v. Klein, 303 U.S. 276 (1938) (unclaimed bonds in registry of federal court); Application of the People of New York, 138 F. Supp. 661 (S.D.N.Y. 1956) (unclaimed bankruptcy dividends); In re Moneys Deposited in United States Dist. Court, 135 F. Supp. 55 (W.D. Pa. 1955), aff'd, 243 F.2d 443 (3d Cir. 1957) (same); Roth v. Delano, 338 U.S. 226, 230-31 (1949) (dictum implying propriety of escheat of depositor's proved claim against insolvent national bank). See also Shestack, supra note 2 , at $56-60,68-69$. 
deposits. ${ }^{6}$ Unclaimed bankruptcy dividends, however, are regulated under a federal power that is intimately concerned with the equities of distribution. ${ }^{7}$ Moreover, a recent amendment to section sixty-six of the Bankruptcy Act, prohibiting state escheat of unclaimed dividends, appears to foreclose the possibility of concurrent federal and state authority. ${ }^{8}$

Originally, section sixty-six required the trustee in bankruptcy to pay into court dividends remaining unclaimed for sixty days following declaration and distribution of the final dividend. ${ }^{9}$ After one year of dormancy, distribution of any funds still unclaimed could be made to creditors whose claims against the bankrupt had not been fully satisfied. ${ }^{10}$ Although the section appeared to envision that the court would undertake this alternate distribution on its own motion, ${ }^{11}$ and that each creditor would share ratably, ${ }^{12}$ it did not explicitly provide for either. ${ }^{13}$ Bankruptcy courts, unequipped to meet the administrative burden, ${ }^{14}$ seldom initiated distribution themselves. They preferred to hold

6. Anderson Nat'1 Bank v. Luckett, 321 U.S. 233, 247-53 (1944); cf. United States v. Klein, stipra note 5 (holding Pennsylvania escheat proceedings determining failure of ownership rights in bonds deposited in federal court not to be an interference with federal courts).

7. See 1 Collder, Bankruptcx \ 0.02 (14th ed. 1956); 3 id. \ 60.01.

8. 70 STAT. 785 (1956), 11 U.S.C. $§ 106$ (Supp. IV, 1957), amending 52 Stat. 875 (1938). For discussion of the amendment's legislative history and provisions, see notes 23, 24 infra and accompanying text.

9. Bankruptcy Act $\S 66,30$ STAT. 564 (1898), as amended, 11 U.S.C. $\S 106$ (1952) (hereinafter cited as Bankruptcy Act $\$ 66$ ). The trustee was required at the same time to file a list of the names and post-office addresses of the persons who had failed to negotiate dividend checks. Bankruptcy Act $\$ 66(\mathrm{a})$; see note 1. supra. Funds that were not distributed after five years were to be turned over to the Federal Treasury, there to be held on order of the district court for missing claimants who might later appear. 28 U.S.C. § 2042 (1952).

10. Bankruptcy Act $\S 66(\mathrm{~b})$ : "Dividends remaining unclaimed for one year shall, under the direction of the court, be distributed to the creditors whose claims have been allowed but not paid in full, and after such claims have been paid in full the balance shall be paid to the bankrupt: Provided, That, in case unclaimed dividends belong to minors, such minors may have one year after arriving at majority to claim such dividends."

The provision concerning minors appears to have had little or no practical effect on the distribution scheme. See S. REp. No. 2722, 84th Cong., 2d Sess. 2-3 (1956).

11. See In re Gubelman, 79 F.2d 976, 977 (2d Cir. 1935) (per curiam), 45 Y ALE L.J. 714 (1936) ; 48 Colun. L. Rev. 959 (1948). See also In re Fielding, 96 Fed. 800, 802-03 (W.D. Mo. 1899). However, once the unclaimed fund was turned over to the Federal Treasury, the provisions of 28 U.S.C. $\$ 2042$ (1952), see note 9 stpra, indicated that the claimant himself or his heirs would have to come forward. See $I n$ re Searles, 166 F.2d 475, 477 (2d Cir. 1948).

12. In re Raabe, Glissman \& Co., 71 F. Supp. 678, 681 (S.D.N.Y. 1947); see the court's discussion in In re Searles, 68 F. Supp. 678 (E.D.N.Y. 1946), modificd and remanded, 166 F.2d 475 (2d Cir. 1948), suggesting that petitioning alternate distributees, unopposed at the hearing, be allowed only a proportional part of the dormant fund. The appellate court remanded on the theory that the overriding requirement of the statute was to effect complete disbursement. See also 4S CoLuM. L. REv. 959. 960 (1948).

13. See note 10 supra.

14. See In re Gubelman, 79 F.2d 976, 977 (2d Cir. 1935), 45 YALE L.J. 714, 715 (1936); 48 Colurr. L. Rev. 959,960 (1948). In amending the section, Congress apparently rejected 
the funds until petition by the original claimant or another creditor qualifying as an alternate distributee. ${ }^{15}$ To insure complete disbursement, ${ }^{16}$ the court, generally after notice by publication, ${ }^{17}$ awarded the full amount to those.creditors who appeared at a subsequent hearing. ${ }^{18}$ And the claim of a petitioning state escheator was honored-at least if no qualified creditor appeared. ${ }^{19} \mathrm{Ob}-$ serving the requirements of due process, a state could determine that all other rights to the dividends had failed and assert its own claim as ultimate beneficiary to the entire fund. ${ }^{20}$ Reasoning that Congress had not intended to restrict such state determination, the courts did not have to decide whether federal bankruptcy power would justify a limitation on this incident of state sovereignty. ${ }^{21}$ But whether a creditor or a state escheator first petitioned, section sixty-six as construed barred "dilatory" creditors from participating on a pro rata basis. ${ }^{22}$

the feasibility of a court-initiated distribution. See S. REP. No. 2722, 84th Cong., 2d Sess. 2 (1956).

15. This procedure appears to have been universally followed, both during the second to fifth years of dormancy when the fund was available for distribution in the registry of the court and after the fifth year when, by the provisions of 28 U.S.C. $\$ 2042$ (1952), the claimant was required to come forward to prove his right to the money. See note 9 supra.

16. See In re Searles, 166 F.2d 475, 477 (2d Cir. 1948) ; In re Raabe, Glissman \& Co., 71 F. Supp. 678, 681 (S.D.N.Y. 1947); note 12 supra.

17. Neither Bankruptcy Act $\S 66$ (b) nor 28 U.S.C. $\S 2042$ (1952) required notice to other qualified creditors before distribution to the petitioning creditor. And the courts did not create such a requirement. See $I n$ re Bishop, 72 F. Supp. 199, 200 (D.N.J. 1947); In re MacMasters, 60 F. Supp. 733, 734 (S.D.N.Y. 1945). But see dissenting opinion of Judge Frank in $I n$ re Searles, supra note 16, at 477-78. But the special master, to whom a creditor's petition was usually referred, often gave notice by publication with court approval. See, e.g., id. at 476; In re Raabe, Glissman \& Co., supra note 16, at 680 .

If the fund had been transferred to the Federal Treasury, however, under the terms of $\$ 2042$ the petitioning creditor was required to give notice of his application to the United States attorney.

18. This hearing was often conducted by a special master. See note 17 supra. If, as was usual, no other qualified creditors appeared in response to notice, the "diligent" creditor or creditors received a windfall at the expense of any other existing members of the same class. See note 23 infra and accompanying text.

19. In the Matter of Moneys Deposited in United States Dist. Court, 135 F. Supp. 55 (W.D. Pa. 1955), aff'd, 243 F.2d 443 (3d Cir. 1957) ; Application of the People of New York, 13S F. Supp. 661 (S.D.N.Y. 1956) (state's right to escheat affirmed but petition denied because of faulty notice in escheat proceedings); cf. In re Thompson's Estate, 192 F.2d 451 (3d Cir. 1951) (escheator's petition claiming succession to the rights of missing alternate distributees held not to entitle state to pro rata share of distribution, when other alternate distributees appeared). For discussion of the implications of this case, see note 43 infra.

20. See cases cited note 19 stpra. The courts were strongly influenced by the Supreme Court's decision in United States v. Klein, 303 U.S. 276 (1938), holding that the states could determine and escheat ownership rights in federal court funds.

21. See cases cited note 19 supra.

22. If the state obtained the fund and its escheat law provided for a period of redemption, a dilatory creditor could presumably recover that amount which he would 
Ostensibly to prevent state escheators or attorneys in partnership with individual creditors from terminating the rights of less informed creditors in a race of diligence for the dormant fund, Congress in 1956 radically altered the section. ${ }^{23}$ The alternate distribution provisions were repealed, and the states were expressly prohibited from obtaining unclaimed dividends by escheat. $^{24}$ As in the old section, unclaimed dividends are to be turned over to the bankruptcy court after sixty days, together with the names and lastknown addresses of their missing owners. ${ }^{25}$ Following five years of dormancy. they are transferred to the Federal Treasury and there held in trust on order of the court for any claimant proving a right to them. ${ }^{26}$ Since no other creditors have contingent rights in the dividends, all possible participants in a race for the funds are eliminated. However, by asserting the perpetual right of the original creditor or his legal successors to receive his share of the fund and

have received had the fund remained on order of the bankruptcy court. See Application of the People of New York, 138 F. Supp. 661, 666 n.4 (S.D.N.Y. 1956). Compare N.Y. Aband. Prop. Law $\$ 1406$ (4) (b) (five-year period of redemption if claimant without actual knowledge), with PA. STAT. A 1 NN. tit. 27, \$ 401 (Supp. 1956) (unlimited period of redemption).

23. 70 Stat. 785 (1956), 11 U.S.C. $\$ 106$ (Supp. IV, 1957), amending 52 Stat. $\$ 75$ (1938). See S. Rer. No. 2722, 84th Cong., 2d Sess. 2-3 (1956); H.R. Rep. No. 1274, 84th Cong., 1st Sess. 1-2 (1955). The senate report includes by reference a report submitted by a special committee of the Judicial Conference of the United States at the March 1953 meeting of the Conference: "[I]n several States a practice has grown up which results in the payment of the balance of the unclaimed dividends to a so-called diligent creditor, thus making it impossible for any of the other creditors thereafter to receive their pro rata share of such funds. . . . [I]n New York one attorney devutes much of his time in prosecuting petitions for diligent creditors. This was also formeriy the case in Chicago due to the activities of one attorney .... [I]n New York and Pennsylvania, State escheaters [sic] closely follow the bankruptcy cases in which all of the funds have not been claimed by the creditors entitled thereto. Such officers have commenced a number of proceedings asking that such funds be escheated to the State." S. REP. No. 2722, sitpra at $2-3$.

On the basis of this report, however, the special committee recommended only that the alternate distribution provisions be repealed and the moneys handled like general court funds under 28 U.S.C. $\$ 2042$ (1952). See JuDicral CoNFERENCE of THE UNITEI States, Report of Proceedings of a Special Session 12 (March 1953). The provision denying state escheat was later proposed by the Bankruptcy Committee of the Judicial Conference. See Judictal Conference of the United States, Refort of Prucendngs of Regular Annual Meeting 10-11 (Sept. 1953). As a result of this later recommendation, bankruptcy dividends are, in fact, not handled like ordinary court funds, since they cannot be disbursed to state escheators. See note 2 supra; cf. United States $v$. Klein, 303 U.S. 276 (1938) ; United States v. Klein, 106 F.2d 213 (3d Cir.), cert. denied, 308 U.S. 618 (1939). See also Shestack, supra note 2 , at $68-70$.

24. 70 Stat. 785 (1956), 11 U.S.C. \& 106 (Supp. IV, 1957), amending 52 STAT. 875 (1938). The section now reads in pertinent part: "Such moneys and dividends shall be deposited and withdrawn as provided in title 28, United States Code, section 2042, and shall not be subject to escheat under the laws of any State."

25. See note 9 sipra.

26. 28 U.S.C. $\$ 2042$ (1952). By virtue of $\$ 2042$, the federal government holus the fund as a trustee. United States v. Klein, 303 U.S. 276 (1938). 
denying the right of states to claim upon a failure of these interests, Congress has chosen a method of resolving the diligence problem which raises more fundamental difficulties.

Amended section sixty-six is subject to constitutional challenge. Even if the bankruptcy power justified perpetual federal control over the devolution of bankruptcy dividends, ${ }^{27}$ generally applicable state laws governing such matters as escheat, inheritance and taxation could not be suspended unless the method selected were reasonably related to the end sought. ${ }^{28}$ But the amendment prohibits claims made under custodial state statutes protecting the rights of federally appointed creditors as well as those brought under laws which vest irrevocable title in the state. ${ }^{29}$ States whose statutes allow the original creditor

27. The courts have not yet been required to determine the validity of the proposition, but they have noted their doubts that the bankruptcy power can extend into this area. See Matter of Moneys Deposited in United States Dist. Court, 243 F.2d 443, 447-48 (3d Cir. 1957) ; Application of the People of New York, 138 F. Supp. 661, 666 (S.D.N.Y. 1956). For discussion of the difficulties involved, see notes 41,44 infra and accompanying text.

28. The constitutionality of federal suspension of otherwise valid state laws must be judged in terms of the relation between the federal prohibition and the ends it seeks to achieve, for the exercise even of enumerated federal powers is limited by what is necessary and proper for their implementation. See U.S. Const. art. I, \& 8, cl. 18; Legal Tender Cases, 79 U.S. (12 Wall.) 457, 531-39 (1870) ; McCulloch v. Maryland, 17 U.S. (4 Wheat.) 316, 421 (1819); The Federalist No. 33 (Scott ed. 1894) (Hamilton); cf. United States v. Darby, 312 U.S. 100, 121-24 (1941); Davis v. Boston \& M.R.R., 89 F.2d 368, 378 ( 1 st Cir. 1937). Hence, if a plan for the devolution of ownership rights to dividends were a proper purpose under the bankruptcy power, Congress could effect a restriction of otherwise valid state laws only on a theory that such laws were actually in conflict with federal design and thus could be reasonably prohibited. Cf. Stellwagen v. Clum, 245 U.S. 605, 611-15 (1918). See also Roth v. Delano, 338 U.S. 226 (1949); Anderson Nat'1 Bank v. Luckett, 321 U.S. 233, 247-53 (1944). If, for example, the bankruptcy law could provide for the unclaimed fund to be held one year for the original owners or their surviving spouses, then to be distributed pro rata to alternate creditors appearing in the next twenty years, then any remainder to be returned to the bankrupt or his federally appointed heirs, state inheritance schemes designating other modes of succession might reasonably be shown to interfere. Similarly, under this hypothetical plan of distribution, a state escheat petition brought before the expiration of twenty years arguably would conflict with the contingent interests of appointed distributees. Suspension of escheat powers until all contingent rights had materialized might thus be warranted.

But the propriety of federal pre-emption would in all cases be limited by reasonable needs for effecting the desired scheme of distribution. Since the amendment contemplates only that the original creditor and his heirs should receive the fund, the validity of the prohibitionary clause depends upon the reasonableness of the proposition that the operation of state escheat law would impair enjoyment of the fund by these nominees.

29. The distinction usually drawn between custodial and noncustodial forms of abandoned property legisiation relates to the manner in which the state asserts its right to the dormant fund. In the former case, the state takes possession by operation of law or adjudication of escheat as "conservator"-i.e., subject to the right of the original owner or his heirs to reclaim at any time. In the latter type, the state takes absolute title, or in one variation, title subject to a limited period of redemption. See N.Y. Aband. Prop. LAw $\$ 1406$ (4) (b) (noncustodial-federal court funds redeemable by any claimant without notice, if made within five years of escheat proceedings); CAL. Code Civ. Proc. $\$ \$$ 
to claim at any time are prevented from escheating even though no conflict with the perpetual right granted the creditor by the amendment would be possible. State interests thus blocked, the federal government is enabled, by a de facto escheat, ${ }^{30}$ to receive a portion of the bankrupt's estate which it could not obtain directly under the bankruptcy power ${ }^{31}$ or through positing a federal right of escheat. ${ }^{32}$

1355, 1540-42 (noncustodial-similar); PA. STAT. ANN. tit. 27, $\S 401$ (Supp. 1956) (custodial-unlimited period of redemption for escheated federal court funds). See also Shestack, supra note 2, at 51; Garrison, supra note 3; Comment, 19 N.C.L. Rev. 372-74 (1941) ; Note, 42 Iowa L. Rev. 399, 404 (1957).

Whether a particular state provision for abandoned funds is truly custodial or noncustodial is not dependent upon its classification as an "escheat" or "abandoned property" statute. Generally, the abandoned property type of legisiation does not provide for a true escheat, since the state does not purport to take title to the fund. Rather, it takes possession from the holder under its police power after a period of dormancy on a theory of preserving the fund for the original owner and his successors. See, e.g., N.Y. ABAND. Prop. LAw \$§ 102, 1404 ; Uniforar Disposition of Unclaimed Propertr Act $\$$ 13, 18-19. See also Shestack, supra note 2, at 51; Garrison, supra note 3, at 305-06. However, even such statutes may provide for a subsequent final adjudication of escheat which vests title in the state. See, e.g., Ky. Rev. Stat. ANv. $\$ \S 393.140(2), 393.230(2)$ (Supp. 1956); Garrison, supra note 3 , at 309 . And, though affording the original owner a lengthy period in which to reclaim possession, they would nevertheless fall outside the definition of custodial legislation used in the text. On the other hand, a law providing for an adjudication of escheat vesting title in the state, and therefore properly denominated an "escheat" statute, may provide for an unlimited period of redemption. Such a statute would, despite its form, be within the text definition of custodial legislation.

Since the state lacks a police power over the bankruptcy court, and since the fund is already safely guarded for rightful owners, the state, when it seeks unclaimed dividends, is practically limited to utilizing some form of escheat proceeding to perfect its title. Shestack, supra note 2, at 67-68. Where the state law gives an unlimited period of redemption to claimants, however, the effect of the state's title is inconsequential; and the escheat law cannot be functionally distinguished from custodial provisions used by the state to secure possession of bank deposits, insurance funds or other dormant moneys within the reach of police regulation.

30. Although the federal government holds unclaimed dividends only as trustee, see note 26 supra and accompanying text, if the original owner or his successors never claim, it is free to utilize the money as it wishes, and thus enjoys a de facto ownership. Hence, while theoretically not asserting a claim to ownerless funds as parens patriac, the government nonetheless displaces the state as ultimate beneficiary. See Application of the People of New York, 138 F. Supp. 661, 666 (S.D.N.Y. 1956).

31. Although the bankruptcy power authorizes federal control over the bankrupt's assets, such control must be exercised for the purpose of achieving an equitable adjustment between the bankrupt and his creditors. See 1 Collier, Bankruptcy If 0.02 (14th ed. $1956) ; 3 i d . \Uparrow 64$, at 2053-54. The United States may, of course, claim a right in the bankrupt's estate as a creditor. See Bankruptcy Act $\$ \$ 64($ a) (4), (5), 52 STat. 874 (1938), as amended, 11 U.S.C. §§ 104(a) (4), (5) (Supp. IV, 1957). But absent such status, no basis exists, statutory or constitutional, for direct federal participation in bankruptcy moneys.

Whether or not federal retention of unclaimed residues of the bankrupt's estate could be justified under the bankruptcy power on a theory of reimbursement for the administrative expense of bankruptcy proceedings presents an interesting conjecture. While the costs of administration are properly payable out of bankrupts' estates, federal legislation has 
Narrow construction of the amendment's prohibitionary clause might overcome these objections. The section in terms prohibits "escheat under the laws of any state." 33 By reading "escheat" to mean the taking of irrevocable title to the fund, courts could honor claims arising under custodial abandoned property legislation. ${ }^{34}$ Such construction, though not unknown, ${ }^{35}$ is admittedly contrary to general American usage ${ }^{38}$ and probable congressional intent. $^{37}$ Still, to save the constitutionality of federal laws and preserve the

so far provided for each estate to pay its own burden. See Bankruptcy Act $\S 62,52$ Stat. 872 (1938), as amended, 11 U.S.C. $\$ 102$ (1952). Federal recoupment of past, or funding of future, administration expenses through abandoned dividends would effect a taxing of one estate with the costs of another. Whether or not such a program would be constitutionally permissible, there is no suggestion that Congress contemplated such use of abandoned dividends. And even if a distribution of costs among all estates would be constitutionally permissible without regard to the actual proportions of costs allocable to each, prohibition of escheat seems a dubious method of effectuating such a purpose. So implemented, the power to offset bankruptcy costs would have only accidental application.

32. See note 3 supra and accompanying text.

33. 70 STat. 785 (1956), 11 U.S.C. \$ 106 (Supp. IV, 1957), amending 52 Star. 875 (1938), see note 24 supra.

34. See note 29 supra.

35. Historically, escheat was conceptually inconsistent with redemption by the original owner or his heirs, since it depended on the absence of a person competent to inherit the property. Although the inquest of office was adopted as a remedial measure to prevent the crown from taking until the unavailability of other claimants was adjudicated, the title of the crown related back to the time of failure of heirs if the inquest found a proper office for the king. Apparently, no procedure was available for redemption by a proper owner should he later have appeared. See Hardman, The Law of Escheat, 4 L.Q. Rev. 318, 322-24, 336-44 (1888).

In distinguishing between custodial and noncustodial forms of abandoned property legislation, though not in a more general context, see note 36 infra, modern commentators use the term "escheat" to signify the process whereby the state becomes owner of the property, either absolutely or subject to a limited redemption period. See Shestack, supra note 2, at 51; Garrison, supra note 3, at 304-06. See also note 29 supra. Moreover, although escheat laws often have redemption periods, such "custodial" features are generally held a matter of legislative grace rather than an integral feature of escheat. Gorney v. Orphans Bd., 93 F.2d 107 (7th Cir. 1937). Arguably, a state claim based on a statute providing for redemption at any time would not really cause an "escheat" in the historical or analytic sense. See note 29 supra.

36. Torn from its feudal context, escheat has been used most generally in America to signify the assumption of ownership by the state when all other ownership fails. See note 3 supra. As such, escheat generally includes all procedures whereby the state takes title to unclaimed realty and personalty, whether or not such title is subject to defeasement by the original owner. See Garrison, supra note 3, at 304-05; Comment, 19 N.C.L. Rev. $372-74$ (1941). And the term has even been applied as a denomination for state sequestration of the dormant fund under "conservator" provisions-usually the first step to escheat (title-passing) of intangibles, see note 29 stpra-although the state takes only as custodian. See, e.g., Jackson, J., dissenting in Connecticut Mut. Life Ins. Co. v. Moore, 333 U.S. 541, 556-64 (1948).

37. The prohibitionary clause of Bankruptcy Act $\$ 66$ was partially directed against the activities of Pennsylvania's escheator. See note 23 sutra. Yet, under the Pennsylvania 
principal aims of Congress, courts have frequently ignored favored interpretations which were not explicitly required..$^{38}$ While states with only noncustodial legislation might be temporarily inconvenienced by the suggested construction, they could easily amend their laws and qualify for unclaimed dividends. ${ }^{39}$ Accordingly, all states would be able to obtain funds insignificant in the operations of the federal government but important in general state programs designed to secure nontax revenue. ${ }^{40}$

statute governing escheat of funds in federal courts, the state takes title "subject to all legal demands on the same." PA. Stat. ANN. tit. 27, \& 334 (Supp. 1956). And "the owner ... his legal representatives, or any person entitled to the possession thereof, may, at any time, apply ... for a refund of the same ... with interest thereon at the rate of two per centum per annum from the date when said moneys were paid . . . to the date of the refund." $I d . \S 401$. To the extent the legislators were aware of the custodial nature of Pennsylvania's statute, they most likely contemplated a broad provision prohibiting state possession under any circumstances. In the first case to arise after the amendment, the Third Circuit took this position without finding discussion necessary. See Matter of Moneys Deposited in United States Dist. Court, 243 F.2d 443, 447-48 (3d Cir. 1957) (amended $\S 66$ would bar Pennsylvania's claim if constitutional, but was inapplicable because the escheat decree had been obtained prior to the effective date of amendment).

This interpretation is supported by the language of the clause- "[dividends] shall not be subject to escheat under the lawes of any State." (Emphasis added.) Apparently recognizing the infinite variety of state abandoned property legislation, Congress probably did not intend the form of state law to be controlling. And, by stating that funds are not to be "subject to" escheat, it may have indicated that state law is not only barred from effecting an escheat but is inapplicable in the first instance.

38. See, e.g., Anniston Mfg. Co. v. Davis, 301 U.S. 337, 351-52 (1937) ; FTC v. American Tobacco Co., 264 U.S. 298 (1924); Elizabeth Arden, Inc. v. FTC, 156 F.2d 132 (2d Cir. 1946). Cf. also Matter of Moneys Deposited in United States Dist. Court, stipra note 37 , at $447-48$.

39. Results of custodial programs have indicated that only a small percentage of moneys received by the state are ever claimed by the original owners or their successors in interest. Of a total abandoned property income of $\$ 32,900,371$ for the years $1944-56$, $N^{N}$ ew York refunded during that same period $\$ 3,839,620$ or approximately $12 \%$ of moneys received. See Note, 42 IowA L. REv. 399, 400 n.5 (1957). Results in other states have been similar. Ibid.

40. Individual unclaimed dividends are usually small in amount, but states have found them significant enough in the aggregate to justify the administrative expense of collection. See Application of the People of New York, 138 F. Supp. 661, 667 (S.D.N.Y. 1956). To minimize this expense, escheat proceedings are generally consolidated; one state petition is brought to the federal court for all unclaimed funds which are at hand in the court registry or on order in the Federal Treasury. See Matter of Moneys Deposited in United States Dist. Court, 243 F.2d 443, 444-45 (3d Cir. 1957) (petition to recover $\$ 7,415-\$ 4,947$ representing unclaimed distributions in equity proceedings, and $\$ 2,468$ unclaimed dividends in bankruptcy); Application of the People of New York, supra at 663 (petition seeking unclaimed funds remaining from 80 separate federal proceedings covering a period of 27 years -74 bankruptcy, 5 equity receivership and 1 criminal). As the result of such procedures in the period 1944-56, New York collected $\$ 371,201$ from federal courts. Note, 42 Iowa L. Rev. 399, 400 n.5 (1957) (net amount realized by New York 1944-56 from comprehensive abandoned property legislation was $\$ 29,060,751$ ). For a general discussion of the revenue aspects of comprehensive abandoned property legislation, see Shestack, supra note 2, at 48-50; Garrison, supra note 3, at 314-17; Comment, S ALA. L. Rev. 39, 41 (1955); Note, 42 Iowa L. Rev. 399, 400-02 nn.46 (1957). 
Even narrow construction, however, does not insure constitutionality. Although Congress clearly may, within a plan designed to secure equitable distribution of the bankrupt's estate, give appropriate distributees ownership rights in the unclaimed fund, the bankruptcy power may not justify control over the ultimate devolution of these rights. ${ }^{41}$ Congress can name original and alternate takers from among those eligible to share in the bankrupt's estate. ${ }^{42}$ And it can prevent operation of state laws which assert a claim prior to that of any of these nominees. ${ }^{43}$ But when state proceedings meeting the require-

41. Since a primary purpose of the bankruptcy power is equitable distribution of the bankrupt's assets among his creditors, Congress has wide discretion in determining which creditors shall share in the bankrupt's estate. See, generally, 3 Collier, BankRUPTCY If 60.01, 64.02, at 2053-54 (14th ed. 1956); 1 REMInGToN, BankruptCY $\$ 17$ (5th ed. 1950). Correlatively, Congress might reasonably grant ownership interests in unclaimed residues of the bankrupt's estate, since they are merely leftover assets. See note 42 infra.

But federal supersession of state laws governing the descent and distribution of such interests would appear without basis in equity or in bankruptcy policy. When the bankrupt's assets have been reduced to cash, final distribution made and the bankrupt discharged, a complete adjustment between the insolvent debtor and his creditors has been achieved. The beneficial interest in leftover funds, since it cannot be in the federal government, see note 26 supra, must be considered to be in the federally appointed distributees. Accordingly, the function of the bankruptcy court would appear merely to order disbursement to a bona fide holder of the appointed distributees' rights. Cf. United States v. Klein, 303 U.S. 276 (1938). Determination of the rules governing the devolution of such rights would seem properly to remain with the state, the traditional authority over the descent and distribution of property interests. See United States v. Burnison, 339 U.S. 87 (1950); United States v. Fox, 94 U.S. 315 (1876).

42. In re Orona Mfg. Co., 269 Fed. 855 (D. Mass. 1921) (holding provisions of old Bankruptcy Act $\S 66$ constitutional).

Alternate distribution provisions are merely an extension of the power of Congress to determine initial distributees. Federal law allotting interests in dormant dividends, whether absolutely or upon condition, does not of itself affect the state's function of determining the rules by which such interests shall devolve. For example, if the federal statute provides that $A$ alone can claim his dividend for one year, but that $B$ and $C$ can also claim if $A$ has not appeared within the year, the state may consistently find that $A, B$ and $C$ have died intestate without heirs. And it can, as parens patriae qualify for $A$ 's claim. See cases cited note 19 supra.

43. Thus, a state would have to adjudicate the interests of all possible takers before it could take by escheat. See In re Thompson's Estate, 192 F.2d 451 (3d Cir. 1951); cf. Corn Exchange Bank Trust Co. v. Empire Trust Co., 206 F.2d 30 (2d Cir. 1953).

In the Thompson case, the court held, under old Bankruptcy Act $\$ 66$ that the claim of Pennsylvania's escheator as successor to the rights of certain alternate distributees did not entitle the state to receive a pro rata distribution with other qualified creditors actually appearing at the federal court hearing. The court refused to examine the adequacy of the state escheat decree-escheat could only be grounded upon the want of any claimants entitled to the fund. Since claimants qualified under $\$ 66$ actually appeared, the court implied, the basis of any escheat proceeding was lacking, and under the diligent creditor rule those creditors appearing took all.

The position of the court is not clear. If the state, within due process limitations, had adjudicated the rights of all possible claimants to the fund, its decree would seemingly have divested subsequently appearing claimants of title to the dividends and have con- 
ments of due process establish the unavailability of all qualified distributees, congressional prohibition would be justified only if the bankruptcy power requires greater protection to ownership than that afforded by due process. ${ }^{44}$

clusively established the escheator's claim. See Hamilton v. Brown, 161 U.S. 256 (1S96). On the other hand, since the state modified its petition so as to seek only the proportional part which would have been due the missing claimants, the court may have proceeded on the theory that the escheat decree was based solely on an adjudication of the rights of those creditors failing to appear.

In a subsequent case, the Thompson court seems to have followed the latter interpretation in holding the state entitled to the fund where no creditors appeared: "And such a decree for escheat, while not equivalent to an assignment,.... [citing Thompson] is undoubtedly an adjudication that the state is entitled as parens patriae to assert the claim of the missing claimant to the moneys in question in the absence of the claimant and of anyone else competent to inherit the claim." In the Matter of Moneys Deposited in United States Dist. Court, 243 F.2d 443, 445 (3d Cir. 1957). For a similar interpretation of Thompson, see Application of the People of New York, 138 F. Supp. 661, 667 (S.D.N.Y. 1956).

44. The bankruptcy power is not without limitations. Although impossible of exact definition, see Wright v. Union Cent. Life Ins. Co., 304 U.S. 502 (1938), its extent must be viewed in light of the purposes for which it was granted-protection of creditors through an equitable distribution of the debtor's assets, protection of the debtor through a process finally discharging his liabilities, and protection of the credit structure through an orderly, efficient system of accomplishing both of the above aims. See Continental III. Nat'l Bank and Trust Co. v. Chicago, R.I. \& Pac. Ry., 294 U.S. 648 (1935) ; Hanover Nat'l Bank v. Moyses, 186 U.S. 181 (1902) ; 1 CollIER, BANKRUPTCY $\{0.02$ (14th ed. 1956); 1 REAINGTON, BANKRUPTCY $\$ 11$ (5th ed. 1950); Kreft, What is the "Subject of Bankruptcies"?, 6 TEMr. L.Q. 141-46 (1932). The determination of whether a federal statute falls within the subject of bankruptcies is in the final analysis dependent upon the reasonableness of its relation to the purposes of the bankruptcy power. Ibid.

The power to modify individual property rights stemming from state law has long been recognized as a necessary ingredient of federal authority to secure bankruptcy aims. See Wright v. Union Cent. Life Ins. Co., supra (federal extension of mortgagor's period of redemption); Kuehner v. Irving Trust Co., 299 U.S. 445 (1937) (modification of landlord's lease). Cf. also Engstrom v. De Vos, 81 F. Supp. 854 (E.D. Wash. 1949). And direct limitations on the powers of state sovereignty have been imposed where such limitations do not cut off the sovereign's interest in the bankrupt's estate and are necessary to secure an orderly administration in bankruptcy. See New York v. Irving Trust Co., 288 U.S. 329 (1933) (order barring claim of state filed after expiration of six-month time limit sustained). The courts have, however, been more solicitous of the state's position where bankruptcy legislation would seriously detract from the traditional attributes of state sovereignty, and they have closely scrutinized the propriety of such exercise of federal power. Compare Ashton v. Cameron County Water Improvement Dist. No. One, 298 U.S. 513 (1936), with United States v. Bekins, 304 U.S. 27 (1938).

In the Bankruptcy Act $\S 66$ amendment, the apparent purpose of Congress is to protect its scheme of distribution by prohibiting state action which might interfere. See note 23 supra. Yet the interests of federally appointed distributees are already protected from captious state procedures by due process requirements. Where state ownership of abandoned dividends is sought, in the absence of actual proof of the creditor's death intestate without heirs, the state must await the termination of a statutory period supporting an inference that all other claims have failed. See, e.g., N.Y. ABand. Prop. LAw $\$ \S 1200-01,1406$ (4) (b) (rebuttable presumption of failure after ten consecutive years of dormancy; five-year redemption period). Furthermore, in its escheat proceedings, the state is required to pursue the best available means of giving notice to all interested parties. Application of the People of New York, supra note 43, at 661 . For analogous requirements in federal bank 
Yet due process has been considered sufficient to protect other property rights from arbitrary state power, ${ }^{45}$ even those stemming from federal adjudications. ${ }^{46}$ To find that bankruptcy dividends require additional safeguards, therefore, is to rule that interests received under the bankruptcy power, whether in the original takers or their successors, enjoy a status above normal holdings. ${ }^{47}$ And if rights derived from the bankruptcy power can be given such a superior position, rights arising under other federal powers would seem equally deserving of preferential treatment. Federal courts thus appear to confront the choice of finding the prohibitionary clause of section sixty-six unconstitutional or allowing a major encroachment on state sovereignty by accepting the position that the federal government can control the devolution of property interests derived from any federal law. ${ }^{48}$

Should the prohibitionary clause be declared unconstitutional, the amendment's principal purpose of preventing the race of diligence could still be

cases, compare First Nat'1 Bank v. California, 262 U.S. 366 (1923), with Anderson Nat'1 Bank v. Luckett, 321 U.S. 233 (1944). For discussion of the relation between due process requirements and redemption periods, see note 54 infra.

45. See U.S. Const. amend. XIV, \& 1; Anderson Nat'l Bank v. Luckett, supra note 44, at 240-52 (depositor's rights in federal bank deposits) ; Cunnius v. Reading School Dist., 198 U.S. 458 (1905) (wife's dower interest in realty); Hamilton v. Brown, 161 U.S. 256 (1896) (heir's interest in real property). Cf. also Security Sav. Bank v. California, 263 U.S. 282 (1923) (state bank's right to retain dormant bank deposits for rightful owner).

46. See United States v. Klein, 303 U.S. 276 (1938) ; United States v. Klein, 106 F.2d 213 (3d Cir.), cert. destied, 308 U.S. 618 (1939). See also Shestack, supra note 2, at $68-70$.

"In this case jurisdiction was acquired by the district court, by reason of diversity of citizenship, to adjudicate the rights of the parties. That function performed, it now retains jurisdiction for the sole purpose of making disposition of the fund under its control, by ordering payment of it to the persons entitled as directed by the federal statute. Beyond whatever is needful and appropriate to the accomplishment of that end, the jurisdiction and possession of the federal district court does not operate to curtail the power which the state may constitutionally exercise over persons and property within its territory." United States v. Klein, 303 U.S. 276, 281-82 (1938).

47. The illusory justification for perpetual federal custody of unclaimed dividends becomes more apparent as the years of dormancy increase. If insulation of the fund from the state would tend to enhance the federal plan of distribution during early years by preventing escheat based on specious presumptions of death without heirs, the original creditor or his heirs are hardly likely to seek the money after the passage of twenty-five or fifty years. And if the state had absolute proof that the original creditor had in fact died without successors, the curious consequence would be that, while all his other property had escheated to the state, the federal government would retain bankruptcy dividends due him for his exclusive enjoyment.

48. The difficulty of this position is illustrated by judicial reaction to cases concerning distribution of unused portions of veterans' benefits granted by the United States. To avoid questions concerning federal invasion of state sovereignty, 46 STAT. 994 (1930), 38 U.S.C. $\$ 450$ (3) (1952), providing that "any [of such funds which] . . . would escheat to the State, shall escheat to the United States" has been construed as a conditional limitation upon a gift. Estate of Lindquist, 25 Cal. 2d. 697, 154 P.2d 879 (1944); Coakley v. Attorney Gen., 318 Mass. 508, 62 N.E.2d 659 (1945); Matter of 
effectuated. ${ }^{49}$ With no alternate distributees in the contest, ${ }^{50}$ the right of the original creditor or his legal successors to receive the dormant dividend would remain secure, subject only to a state claim based on a determination that such rights had failed. ${ }^{51}$ By demanding strict state adherence to due process requirements, the federal disbursing court could minimize the possibility of premature termination of the original creditor's interest..$^{52}$ Thus, a state could be required to show that its escheat claim was founded either upon proof of the creditor's death without successors, ${ }^{53}$ or upon a presumption of death or abandonment supported by a sufficient lapse of time. ${ }^{54}$ In either case,

Hammond, 2 App. Div. 2d 160, 154 N.Y.S.2d 820 (2d Dep't 1956). These cases are readily distinguishable from unclaimed dividends which are not attributable to the federal government in the first instance.

The courts have adopted a rationale similar to that of the pension cases in federalstate controversies over the property of veteran inmates of federal rest homes. See United States v. Stevens, 302 U.S. 623 (1938) ("contract" with veterans' home, valid under state law, entitled home to receive property of veteran when property unclaimed for five years). See also Tax Comm'n v. Rife. 119 Ohio St. 83, 162 N.E. 390 (1928).

49. See note 23 supra.

50. See text at note 24 supra.

51. Under these circumstances, the incentive a state might have to reduce its statutory waiting period in order to "arrive" at the federal disbursing court before a diligent attorney-creditor claimant took the entire fund would be abated, since, at most, a petitioning creditor could receive only his original dividend. For the same reason, attorneys would probably find partnership arrangements with creditors unprofitable. See notes 18 , 23 supra and accompanying text. A race between escheators of different states, however, would remain possible, and though checked by due process review in the federal courts, could be adjusted, most probably, only through conflict of laws doctrines. See note 2 supra.

52. The federal disbursing court is not unaided in reviewing state escheat procedures. By the terms of 28 U.S.C. $\$ 2042$ (1952), the United States attorney must be given notice of state petitions for unclaimed moneys, see note 17 supra, and most state statutes have similar provisions. See CaL. Code Civ. Proc. \$1530; N.Y. Aband. Prop. Law $\$ 1206$.

53. This is a recognized ground of escheat in all jurisdictions. Garrison, supra note 3 , at 304. But the administrative cost of an adjudication to determine the fact of the original owner's death intestate without heirs reduces the likelihood of a state's claim being so founded.

54. Because of the difficulties in proving that missing creditors have died intestate without heirs or have in fact abandoned their claims, some states have expressly provided for a rebuttable presumption of intestate death or of abandonment in the context of escheat of federal court funds. If no claimants appear at state proceedings, this presumption will support an adjudication that the dividends have escheated. See N.Y. ABAND. Prop. LAw $\$ 1201$ (presumption arising after 10 years of dormancy); PA. STAT. ANN. tit. 27, $\$ 334$ (Supp. 1956) (presumption after 7 years of dormancy); CAI. ConE CIV. Proc. $\S 1530$ (presumption after 5 years of dormancy). The length of this period is especially significant in protecting the rights of absent claimants, since notice is at best a weak safeguard. See Application of the People of New York, 138 F. Supp. 661, 668 (S.D.N.Y. 1956). But evaluation of whether a specific statutory waiting period is within constitutional limitations cannot be made without consideration of related statutory provisions concerning notice and redemption periods. Thus, in the related area of fcderal bank deposits, a state statute providing for surrender of demand deposits after ten years, then subjecting them to escheat at any time with a five-year redemption period for claimants without notice, and requiring notice by publication before surrender, was 
the bankruptcy court would be entitled to deny disbursement on due process grounds where the state did not, in providing notice of its escheat proceedings, fully utilize the list of missing creditors' names and last-known addresses on file with the court. ${ }^{55}$ Within this framework, the states' traditional right to escheat would be retained, the federal purpose to protect the interests of missing creditors subserved.

held consonant with due process requirements. Anderson Nat'1 Bank v. Luckett, 321 U.S. 233, 236-38, 241-42 (1944). But where state law provided for escheat of bank deposits after twenty years of dormancy, with no provision for notice or redemption, the waiting period was considered insufficient in itself to prevent "confiscation" of the depositor's property. See First Nat'l Bank v. California, 262 U.S. 366, 370 (1923). Compare ibid., with Anderson Nat'l Bank v. Luckett, supra at 250-52.

Shorter periods than those customarily used for bank deposits would probably be reasonable in state laws governing unclaimed bankruptcy dividends, especially when redemption privileges are granted; for attendant circumstances more reasonably indicate that the interest of the original claimant has in fact failed. Delivery to the missing creditor by the trustee in bankruptcy has already been attempted. See note 1 supra. And, normally, a creditor who is available to claim and desires his dividend will not choose to refrain from collecting it in order to utilize the federal court as a depository.

55. See note 9 sitpra. Thus, the state could be required to include the names and lastknown addresses of missing creditors in its notice by publication and to mail notice of the pending escheat proceedings to those addresses. See Application of the People of New York, supra note 54, at 667-70. 